\title{
PENYUSUNAN PAKET WISATA PEDESAAN UNTUK MENINGKATKAN KOMPETENSI MASYARAKAT DESA ALAMENDAH KABUPATEN BANDUNG
}

\author{
${ }^{1}$ Endang Komesty Sinaga, ${ }^{2} \mathrm{Cucu}$ Kurniati, ${ }^{3}$ Nuraeni Handayaningrum \\ ${ }^{1}$ Sekolah Tinggi Pariwisata NHI Bandung \\ 2Sekolah Tinggi Pariwisata NHI Bandung \\ 3Sekolah Tinggi Pariwisata NHI Bandung \\ ${ }^{1}$ enk@stp-bandung.ac.id \\ ${ }^{2}$ cuk.stpb@yahoo.com \\ ${ }^{3}$ ningrum0312@gmail.com
}

\begin{abstract}
Abstrak
Salah satu kawasan pariwisata andalan Provinsi Jawa Barat yang memiliki prioritas untuk dikembangkan oleh Pemerintah Kabupaten Bandung adalah kawasan wisata Alamendah. Kawasan Wisata Alamendah memiliki keanekaragaman budaya serta keahlian masyarakat setempat dalam bercocok tanam berupa produk unggulan yaitu pertanian strawberry, sayuran dan perkebunan the serta terdapat industri pembuatan kopi luwak. Produk unggulan di desa ini berupa aneka makanan olahan strawberry seperti dodol, selai, permen berbahan strawberry serta kerajinan tangan lainnya. Untuk meningkatkan kualitas dan daya saing destinasi pariwisata yang dapat menaikkan jumlah dan kualitas kunjungan wisatawan, maka kegiatan pengabdian masyarakat perlu dilakukan dengan judul " Penyusunan Paket Wisata Pedesaan untuk Meningkatkan Kompetensi Masyarakat Desa Alamendah Kabupaten Bandung.".

Adapun tujuan pengabdian masyarakat yang dilakukan adalah untuk memberdayakan potensi masyarakat Desa Wisata Alamendah. Metode yang digunakan dalam kegiatan pengabdian kepada masyarakat adalah pelatihan dan pendampingan bagi masyarakat.

Hasil kegiatan dari program pengabdian masyarakat ini adalah pemahaman masyarakat dalam membuat paket wisata dengan memanfaatkan potensi yang dimiliki, terciptanya beberapa paket wisata baru yang inovatif dan kreatif serta masyarakat mampu mengemas dan menangani operasional tour secara langsung.
\end{abstract}

Kata kunci : kompetensi masyarakat, paket wisata, wisata pedesaan,

\section{PENDAHULUAN}

Pembangunan pariwisata merupakan bagian integral dari pembangunan nasional yang pelaksanaannya melibatkan 5 (lima) stakeholder kunci atau yang disebut dengan pentahelix yakni pemerintah, swasta dan masyarakat, akademisi dan media. Pengembangan sektor ini dilaksanakan secara lintas sektoral yang melibatkan banyak institusi baik tingkat lokal, regional, nasional bahkan internasional. Untuk mengoptimalisasi kontribusi 
manfaat sektor pariwisata, diperlukan pola perencanaan dan pengelolaan yang berkesinambungan.

Salah satu kawasan pariwisata andalan Provinsi Jawa Barat yang memiliki prioritas untuk dikembangkan oleh Pemerintah Kabupaten Bandung adalah kawasan wisata Alamendah. Kawasan Wisata Alamendah memiliki keanekaragaman budaya serta keahlian masyarakat setempat dalam bercocok tanam berupa produk unggulan yaitu pertanian strawberry, sayuran dan perkebunan the serta terdapat industri pembuatan kopi luwak. Produk unggulan di desa ini berupa aneka makanan olahan strawberry seperti dodol, selai, permen berbahan strawberry serta kerajinan tangan lainnya. Potensi desa wisata Alamendah berbeda dari desa wisata lainnya yaitu memiliki makanan olahan yang berbahan baku buah strawberry yang lebih variatif jika dibandingkan dengan desa wisata lainnya.

Peningkatan kualitas dan daya saing destinasi pariwisata tidak hanya dalam bentuk intervensi pengembangan sarana dan prasarana tetapi juga mencakup penataan, kualitas pelayanan, promosi destinasi serta pengelolaan usaha kecil menengah (UKM) untuk dapat meningkatkan jumlah dan kualitas kunjungan wisatawan.

Agar pembangunan ekonomi destinasi pariwisata dapat dilakukan secara optimal dan merata di seluruh wilayah ini diperlukan adanya suatu pola pengelolaan pengembangan usaha pariwisata yang komprehensif, strategis, efisien dan efektif yang menguntungkan semua pemangku kepentingan. Pola perencanaan dan pengelolaan usaha pariwisata diperlukan secara berkesinambungan dengan dukungan banyak pihak yang dimulai dari tahapan dan proses perencanaan, operasional dan pemantauan.

Kegiatan pengabdian masyarakat yang dilakukan terkait dengan bagaimana masyarakat di Desa Wisata Alamendah merancang suatu bisnis atau usaha dengan kearifan lokal, dalam hal pengemasan dan membuat harga jual produk yang lebih kompetitif.

Desa Wisata merupakan "Suatu kawasan pedesaan yang menawarkan keseluruhan suasana yang mencerminkan keaslian pedesaan baik dari kehidupan sosial ekonomi, sosial budaya, adat istiadat, keseharian, memiliki arsitektur bangunan dan struktur tata ruang desa yang khas, atau kegiatan perekonomian yang unik dan menarik serta mempunyai potensi untuk dikembangkannya berbagai komponen kepariwisataan, misalnya : atraksi, akomodasi, makanan-minuman, cindera-mata, dan kebutuhan wisata lainnya. Lebih lanjut Desa wisata merupakan suatu bentuk integrasi antara atraksi, akomodasi dan fasilitas pendukung yang disajikan dalam suatu struktur kehidupan masyarakat yang menyatu dengan tata cara dan tradisi yang berlaku Selain berbagai keunikan tersebut, kawasan desa wisata juga dipersyaratkan memiliki berbagai fasilitas untuk menunjangnya sebagai kawasan tujuan wisata. Berbagai fasilitas ini akan memudahkan para pengunjung desa wisata dalam melakukan kegiatan wisata. Fasilitasfasilitas yang seyogyanya ada di suatu kawasan desa wisata antara lain: sarana transportasi, telekomunikasi, kesehatan, dan akomodasi. Khusus untuk sarana akomodasi, desa wisata dapat menyediakan sarana penginapan berupa pondok-pondok wisata (homestay) sehingga para pengunjung dapat merasakan suasana perdesaan yang masih asli. 
Adapun persoalan yang dihadapi masyarakat Desa Wisata Alamendah, meliputi, a) belum mampu meningkatkan pendapatan masyarakat sekitar, b) belum mampu mengemas produk wisata dengan cara-cara yang inovatif dan kreatif, c) masih memerlukan pemahaman tentang pengemasan produk wisata menjadi paket wisata yang menari, d) belum optimal dalam membangun jejaring dan kerjasama dengan pihak travel agent/komunitas budaya dalam memasarkan dan menjual produk wisata. Oleh karena perlu dilakukan penyuluhan dan pendampingan kepada para pelaku Usaha Kecil Menengah (UKM) termasuk di dalamnya pembenahan sumber daya manusia agar mereka memiliki jiwa ekonomi kreatif dalam meningkatkan pertumbuhan ekonomi masyarakat Desa Wisata Alamendah.

Tujuan pengabdian masyarakat adalah untuk 1) memberdayakan potensi masyarakat Desa Wisata Alamendah dalam meningkatkan pendapatan keluarga melalui peningkatan usaha ekonomi produktif., 2) memberikan pemahaman kepada masyarakat dalam membuat paket wisata yang baru yang dapat dijual kepada wisatawan. 3) peningkatan jumlah wisatawan yang berkunjung ke Desa Wisata Alam Endah.

Sasaran kegiatan pengabdian masyarakat adalah a) terciptanya paket wisata baru dan lebih variatif, b) mampu menyusun paket wisata, c) mampu mengemas paket wisata, d) mampu menangani operasional tour.

Adapun persoalan yang dihadapi masyarakat Desa Wisata Alamendah adalah belum mampu meningkatkan pendapatan masyarakat sekitar, belum mampu mengemas produk wisata dengan cara-cara yang inovatif dan kreatif, masih memerlukan pemahaman tentang pengemasan produk wisata menjadi paket wisata yang menarik, dan belum optimal dalam membangun jejaring dan kerjasama dengan pihak travel agent/komunitas budaya dalam memasarkan dan menjual produk wisata.

\section{METODE}

Metode pelaksanaan yang digunakan dalam kegiatan pengabdian masyarakat ini adalah

menghubungi Kepala Desa untuk mendiskusikan topik yang hendak diabdikan yaitu pemberdayaan usaha wisata pariwisata bagi masyarakat dan mencari data jumlah daftar usaha pariwisata, menyelenggarakan pelatihan, dengan materi: a) melakukan inventarisasi potensi atraksi wisata, aktivitas wisata, aksesibilitas, dan amenitas, menyusun rencana perjalanan wisata, menghitung harga paket perjalanan wisata, mengemas paket perjalanan wisata, dan penanganan perjalanan wisata. Model kegiatan workshop dalam perencanaan dan perancangan paket wisata, model pendampingan masyarakat Desa Wisata Alamendah, dan wawancara awal dan feed back terhadap seluruh kegiatan pelatihan.

\section{HASIL DAN PEMBAHASAN}

\section{Profil Desa Wisata Alamendah}

Desa Alamendah sebuah desa yang memiliki banyak kekayaan alam dan potensi untuk dijadikan sebagai Destinasi Pariwisata . Desa ini terletak di kecamatan Rancabali Kab. Bandung, terletak di daerah pegunungan yang berjarak kurang lebih 40 KM dari Kota Bandung . Desa Alamendah adalah merupakan salah satu desa dari 7 desa yang berada di wilayah Kec. Rancabali Kab. Bandung dengan batas-batas sebagai berikut:

Sebelah timur berbatasan dengan Desa Sugihmukti Kecamatan Rancabali, sebelah selatan dengan Desa Patengan Kecamatan Rancabali, sebelah barat Desa Lebak Muncang Kecamatan Rancabali, dan sebelah utara Desa Panundaan Kecamatan Ciwidey.

Mayoritas mata pencaharian
enduduknya adalah sebagai petani dan Lingkungan Hidup dan Bencana 696 
buruh tani, produk hasil pertanian saat ini yang menjadi unggulan adalah strawberry dan sayur mayur. Selain bermata pencaharian sebagaimana diatas terdapat juga masyarakat yang bergerak dalam pengolahan hasil budidaya strawberry dan kerajinan, perdagangan, jasa perbengkelan, peternakan sapi perah, jasa angkutan, buruh dan wiraswasta lainnya.

Gambar 1

\section{Peta Wisata Desa Alamendah}

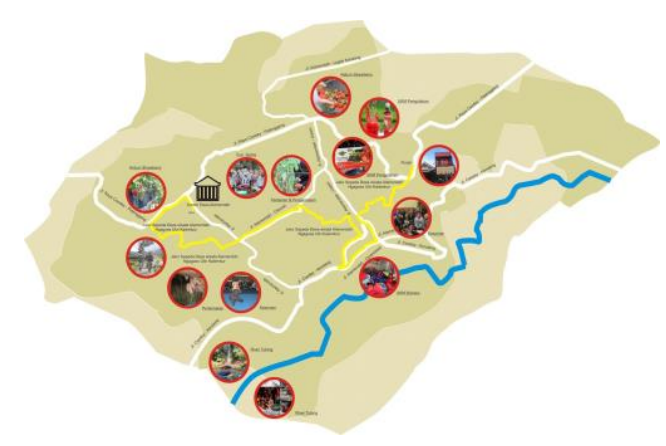

2. Bentuk usaha Desa Wisata

Alamendah

Adapun bentuk usaha Desa Wisata Alamendah yang diusahakan oleh masyarakat setempat meliputi: a) Wisata "Ngagoes Ulin Kalembur" adalah kegiatan bersepeda santai merupakan salah satu paket wisata petualangan yang disuguhkan oleh pihak Dawala. Dalam kegiatan ini pengunjung dapat bersepeda sambil menikmati suasana pedesaan, selain itu pengunjung akan diajak ke home industry pengolahan oleh-oleh berupa makanan ringan khas Desa Alamendah maupun produksi bantal stroberi. Saat mengunjungi home industry, pengunjung juga dapat mengikuti kegiatan produksi. Kegiatan wisata yang ada yaitu wisata agro yang bisa dikembangkan oleh siapapun dengan mengedepankan setiap budidaya, baik tanaman hortikultura, perkebunan, tanaman pangan, hingga peternakan. Desa Alamendah sendiri memiliki potensi agrowisata yang sangat beranekaragam, seperti: perkebunan strawberry, jeruk dekopon, tanaman hortikultura dan peternakan sapi penghasil susu. Di Desa Alamendah kita bisa mengembangkan potensi-potensi tersebut dan memajukan perekonomian masyarakat di Desa Alamendah. Kebun stroberi di Desa Alamendah terkenal memiliki ciri buahnya yang relatif lebih besar, segar dengan warna yang merah menyala, rasa manis dan sedikit rasa asam, dan ini tentunya akan sangat menggugah selera bagi siapa pun untuk mengonsumsinya langsung di tempat ini. Lokasi wisata petik strawberry ini sebenarnya bisa kita temukan di sepanjang jalan kawasan wisata di Desa Alamendah, Kecamatan Rancabali, Kabupaten Bandung. Selain perkebunan, sebagian masyarakat Desa Alamendah juga melakukan kegiatan peternakan, salah satunya adalah pemerahan susu sapi dimana susu ini biasanya dijual ke koperasi. Selain dijual ke koperasi, ada juga produsen susu yang mengolah susu menjadi yoghurt. Kegiatan pemerahan susu sapi ini masuk ke dalam aktivitas wisata yang ada dalam paket wisata yang dibuat oleh Dawala. Dalam kegiatan memerah susu sapi ini wisatawan dapat mencoba pengalaman baru berupa memeras susu sapi, memandikan sapi, dan mencoba susu segar yang baru diperas. Kegiatan wisata lain yang tidak kalah pentingnya adalah bermain alat musik tradisional, Karinding yaitu alat untuk mengusir hama di sawah. Suara yang dihasilkan dari getaran jarum karinding biasanya bersuara rendah low decible. Suaranya dihasilkan dari gesekan pegangan karinding dan ujung jari yang ditepuktepakkan, biasanya terdengar seperti suara wereng, belalang, jangkrik, burung, dan lain-lain yang jaman sekarang dikenal dengan istilah ultrasonik. Calung adalah alat musik sunda yang telah berkembang sejak lama di Jawa Barat. Alat musik ini dimainkan bersamaan dengan alat musik lain seperti angklung dan terbuat dari bambu yang berjenis Awi Wulung dan Awi Temen. Kesenian tradisional masyarakat Jawa Barat yang terkenal adalah kecapi suling. Kesenian ini merupakan warisan buhun leluhur masyarakat Sunda secara turun temurun. Dengan suara suling sebagai vokal dan kecapi sebagai pengiring sekaligus pengatur tempo, kesenian ini mampu menyihir masyarakat dunia dengan keharmonisannya. 
Gambar 2 "Ngagoes Ulin Kalembur"

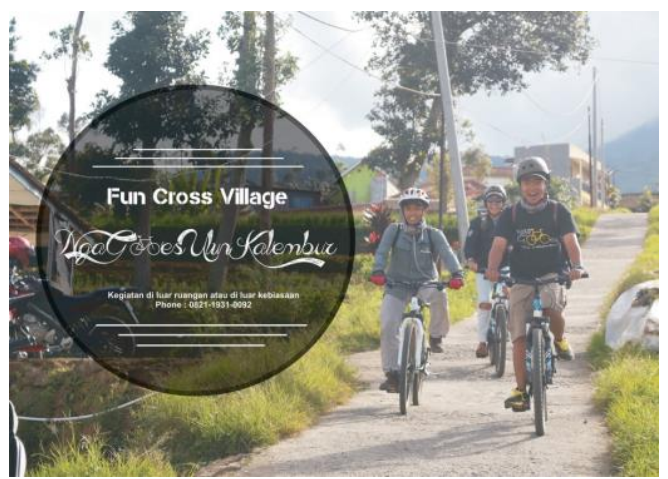

Gambar 3 Wisata Bercocok Tanam

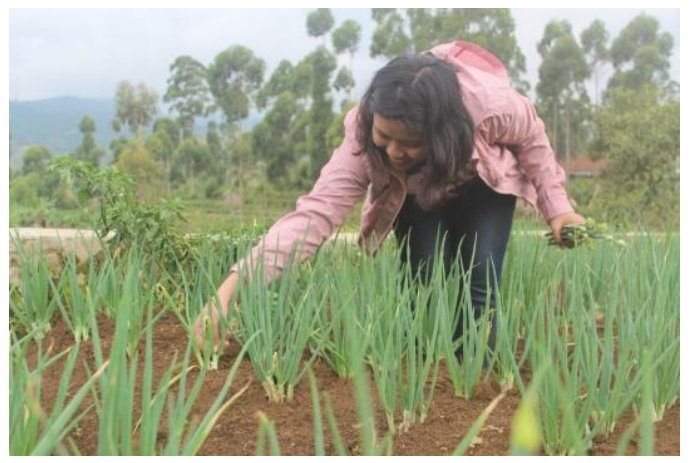

Gambar 4 Wisata Memetik Strawberry

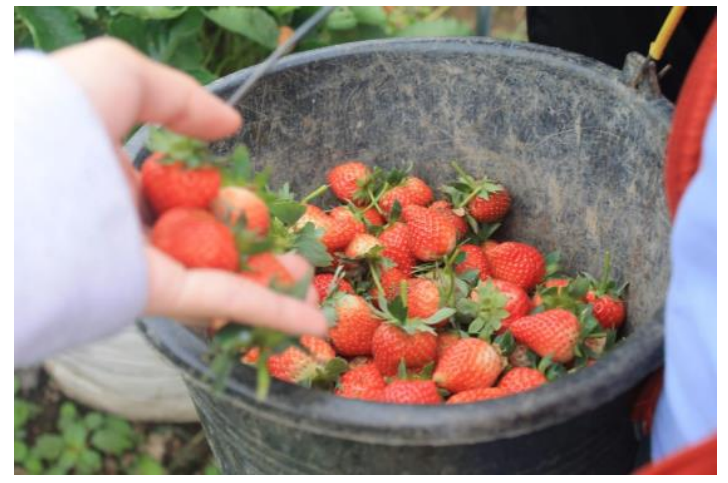

Gambar 5 Wisata Memerah Susu

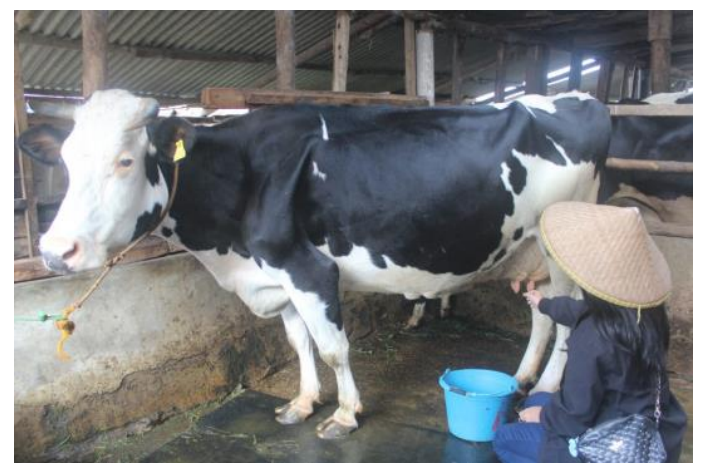

Gambar 6 Bermain Alat Musik Tradisional

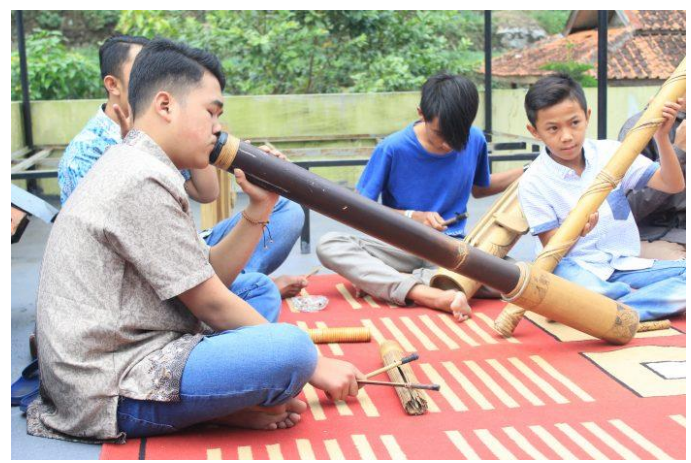

\section{Kegiatan Pelatihan Peningkatan}

\section{Kompetensi Masyarakat}

Kegiatan pengabdian masyarakat dilaksanakan selama tiga hari, dengan memberikan pelatihan kepada masyarakat Desa Wisata Alamendah. Identifikasi Potensi Wisata Desa Alamendah adalah topik pelatihan pertama yang diberikan kepada masyarakat. Kegiatan ini diikuti oleh 25 orang yang terdiri dari Pokdarwis / Kompepar dan Karang Taruna Desa Wisata Alamendah dan masyarakat setempat. Umumnya latar belakang dari masyarakat setempat adalah SD, SMP, SMU dan Diploma. Masyarakat diberikan pemahaman tentang jenis-jenis atraksi wisata yang ada di Desa Alamendah, mengklasifikasi sesuai jenis atraksi, dan memetakan sesuai daerah masing-masing. Sesi berikutnya adalah menyusun rencana perjalanan wisata berdasarkan identifikasi jenis-jenis atraksi yang sudah dibuat. Dalam sesi ini masyarakat dibagi menjadi beberapa kelompok dan mencoba menyusun rencana perjalanan atau paket wisata dengan menginap selama satu atau dua hari. Topik berikutnya adalah mengemas paket perjalanan wisata desa., dan topik yang terakhir adalah penanganan perjalanan wisata desa. Masyarakat diberikan kesempatan untuk mempresentasikan hasil paket wisata yang berhasil dibuat, dan kemungkinan untuk dijual kepada wisatawan. Kegiatan yang dilakukan di Desa Wisata Alamendah mendapat tanggapan yang sangat positif, mengingat masyarakat 
desa tersebut masih kesulitan dalam pembuatan paket wisata. Peserta yang mengikuti kegiatan ini adalah masyarakat yang belum pernah mendapat pelatihan pembuatan paket wisata sebelumnya, sehingga kegiatan ini menjadi pengetahuan yang baru bagi mereka. Dampak hasil dari kegiatan ini diharapkan menambah motivasi masyarakat Desa Wisata Alamendah untuk mulai membuat paket-paket wisata baru untuk membantu perekonomian masyarakat secara umum. Masyarakat mendapat pemahaman mengenai pembuatan paket wisata dan sudah dapat membuat paket wisata yang berkaitan dengan Desa Wisata Alamendah.

Gambar 7 Kegiatan Pembukaan Pengabdian Masyarakat

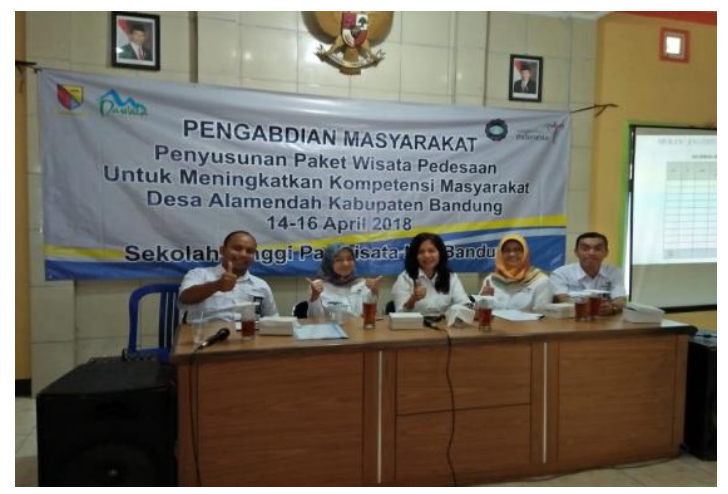

Gambar 8 Kegiatan Pemberian Souvenir kepada Desa Alamendah

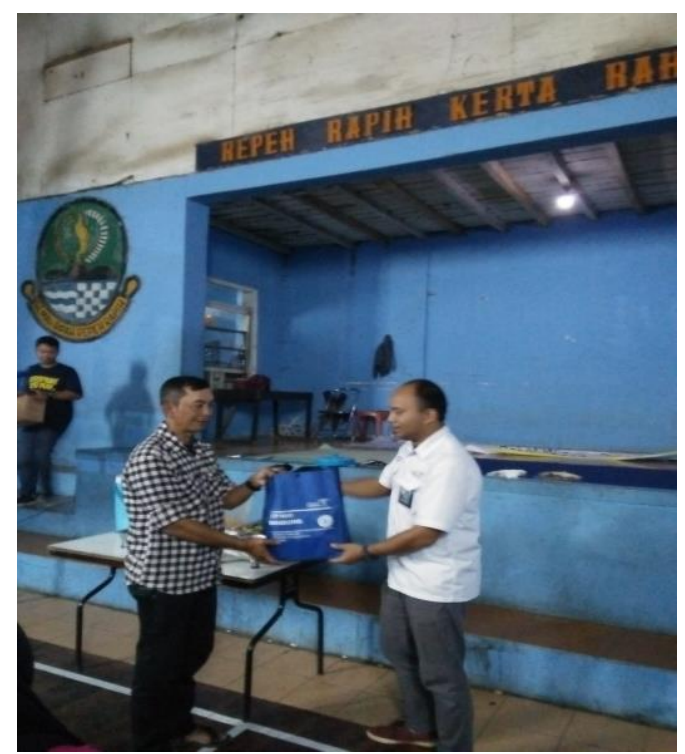

Gambar 9 Kegiatan Pelatihan Penyusunan Paket Wisata

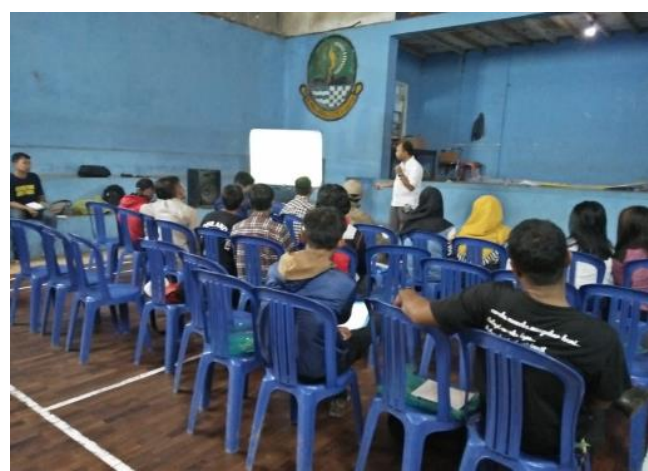

\section{KESIMPULAN}

Desa Wisata Alamendah memiliki potensi wisata yang besar dan sudah sepatutnya dikembangkan, dengan mempersiapkan masyarakat dan memberikan pemahaman agar dapat menyusun paket wisata yang inovatif dan kreatif. Perlu kerjasama yang intensif dengan pihak stakeholder agar dapat memaksimalkan partisipasi masyarakat dalam mengembangkan pariwisata di Desa Wisata Alamendah. Pendampingan yang konsisten dari pemerintah daerah khususnya bidang pariwisata agar dapat meningkatkan kompetensi masyarakat secara berkelanjutan.

\section{REFERENSI}

Administrator. (2016). Sejarah Desa Alamendah Kecamatan Rancabali Kabupaten Bandung. Tersedia: http://www.alamendah.desa. $\mathrm{id} /$ first/artikel/99 [diakses pada tanggal 6 November 2018]

Administrator. (2016). Wilayah Desa. Tersedia: http://www.alamendah.desa. $\mathrm{id} /$ first/artikel/98 [diakses pada tanggal 11 November 2018]

Lingkungan Hidup dan Bencana 
Administrator. (2017). Lokasi

Outbound Eksotis di

Ciwidey Bandung Selatan.

Tersedia:

https://duniaoutbound.com/l

okasi-outbound-eksotis-di-

ciwidey- bandung-

selatan/.html [diakses pada

tanggal 21 November 2018]

Asmidar, Yuni. (2015). Evaluasi Potensi agrowisata di Desa Alamendah Kecamatan Rancabali Kabupaten Bandung, 19-

20.https://repository.ipb.ac.i d/bitstream/handle/1234567 89/74466[diakses pada tanggal 17 November 2018

Dispora Bandung. Penetapan Desa Wisata Alamendah. http://www.bandungkab.go.i d/arsip/ditetapkan-10-desawisata [diakses pada tanggal 20 November 2018]

Iqbal, Donny. (2016). Owa Jawa, Primata Setia dari Tatar Sunda.Tersedia: http://www.mongabay.co.id/ 2016/02/13/owa-jawaprimata-setia-dari- sunda/ [diakses pada tanggal 21 November 2018]

Mardiana, Dian. (2015). Saung Gawir Ciwidey - The Best Resto \& Bungalow. Tersedia: https://tempatwisatadibandu ng.info/saung-gawirciwidey/ [diakses pada tanggal 6 November 2018]

Mardiana, Dian. (2017). Ciwidey Valley Resort - Review Fasilitas/Wahana \& Info Harga Tiket Masuk. Tersedia: https://tempatwisatadibandu ng.info/ciwidey-valleyresort-hot-spring- water/ [diakses pada tanggal 6 November 2018]
Mardiana, Dian. (2018). Kebun Strawberry Ciwidey - Peta Lokasi \& Harga Tiket Masuk. Tersedia: https://tempatwisatadibandu ng.info/kebun-strawberryciwidey/ [diakses pada tanggal 5 November 2018]

Puteri, Lisyanto dan Salsabila. (2018). Aksesibilitas menuju atraksi wisata alam di kecamatan rancabali. Bandung: journal barista.

Riky. (2018). 'Calung' Alat Musik yang Menghasilkan Harmoni Indah. Tersedia: https://www.indonesiakaya. com/jelajahindonesia/detail/calung-alatmusik-yang-menghasilkanharmoni-indah [diakses pada tanggal 21

November 2018]

$\begin{array}{lr}\text { SMAN } & \text { Bandung, } \\ \text { Siswa. } & \text { (2018). } \\ \text { Karinding. } & \text { Tersedia: } \\ \text { http://pandoe.rumahseni2.ne } \\ \text { t/nusantara/sunda/karinding/ } \\ \text { [diakses pada } & \text { tanggal 21 } \\ \text { November } & 2018\end{array}$


